\title{
Pengembangan Literasi Dasar dalam Meningkatkan Minat Membaca dan Menulis pada Anak Usia Dini di Perumahan Indah Permai Desa Petatal
}

\author{
Abd. Rahman ${ }^{1 *}$, Enjely Putri Marpaung ${ }^{2}$, Husni Fazari Lubis ${ }^{3}$, Melly Nia \\ Fajriani Sinaga ${ }^{4}$, Zuhrinal M. Nawawi ${ }^{5}$ \\ ${ }^{1}$ Universitas Islam Negeri Sumatera Utara Medan, Indonesia \\ ${ }^{2}$ Universitas Islam Negeri Sumatera Utara Medan, Indonesia \\ ${ }^{3}$ Universitas Islam Negeri Sumatera Utara Medan, Indonesia \\ ${ }^{4}$ Universitas Islam Negeri Sumatera Utara Medan, Indonesia \\ ${ }^{5}$ Universitas Islam Negeri Sumatera Utara Medan, Indonesia \\ * Corresponding Author. E-mail: ${ }_{\text {1abdullrahman2699@gmail.com }}$
}

\begin{tabular}{|l|l|l|}
\hline Receive: 03/02/2021 & Accepted: 20/02/2021 & Published: 01/03/2021
\end{tabular}

\begin{abstract}
Abstrak
Kuliah Kerja Nyata (KKN) merupakan kegiatan sosial kemasyarakatan bagi mahasiswa yang sedang kuliah. Kegiatan KKN menempatkan mahasiswa dalam kehidupan sosial di masyarakat dan hidup serta berinteraksi dengan masyarakat dalam membantu dan bermanfaat bagi desa dan masyarakat. Kegiatan KKN yang dilakukan adalah mengadakan seminar dengan tema literasi pada anak usia dini. Seminar ini bertujuan untuk mengembangkan literasi dasar anak dalam meningkatkan minat membaca dan menulis. Seminar literasi ini diadakan di Perumahan Indah Permai, Desa Petatal, Kabupaten Baru Bara. Metode penelitian yang digunakan adalah penelitian lapangan. Penelitian ini termasuk dalam penelitian deskriptif kualitatif. Untuk teknik pengumpulan data menggunakan teknik observasi, wawancara dan dokumentasi. Tujuan pengembangan literasi dasar pada anak sejak dini adalah untuk melatih anak membaca dan menulis sejak dini serta menumbuhkan minat membaca dan menulis. Anak-anak di Desa Petatal hanya membaca buku dan menulis saat belajar di sekolah dan jarang membaca buku dan menulis saat di rumah. Hal inilah yang menjadi salah satu penyebab rendahnya minat baca tulis.
\end{abstract}

Kata Kunci: Kuliah Kerja Nyata, Literasi, Minat Baca dan Tulis, PAUD.

Basic Literacy Development in Increasing Interest in Reading and Writing in Early Childhood at Indah Permai Housing, Petatal Village

\begin{abstract}
Real Work Lecture (KKN) is a community social activity for students who are in college. The KKN activity places students in social life in society and lives and interacts with the community in helping and benefiting the village and the community. The KKN activity carried out was holding a seminar with the theme of literacy aimed at early childhood. The seminar aims to develop children's basic literacy in increasing their interest in reading and writing. This literacy seminar was held at Housing Indah Permai, Petatal Village, Baru Bara Regency. The research method used is field research. The research is included in descriptive qualitative research. For data collection techniques using observation techniques, interviews and documentation. The purpose of developing basic literacy in children from this point on is to train children to read and write from an early age and to foster interest in reading and writing. The children in Petatal Village only read books and write while studying at school and rarely read books and write while at home. This is one of the causes of low interest in reading and writing literacy.
\end{abstract}

Keywords: Real Work Lecture, Literacy, Interest Reading and Writing, Early Childhood. 


\section{Pendahuluan}

Kuliah Kerja Nyata (KKN) yaitu suatu kegiatan tingkat perguruan tinggi yang menempatkan mahasiswa/i di lingkungan masyarakat atau disuatu desa dan hidup bersama masyarakat tersebut dalam membantu dan mendampingi masyarakat dalam memanfaatkan sumber daya alam dan sumber daya manusia untuk mengatasi masalah yang ada di masyarakat dalam waktu tertentu. Kuliah kerja nyata atau KKN bisa disebut sebagai realita sosial atau peristiwa yang terjadi di kehidupan sehari-hari di lingkungan masyarakat.

Selama berlangsung kuliah kerja nyata (KKN) mahasiswa/i di hadapkan dengan berbagai rintangan sekaligus merupakantantanganagar bagaimana untuk membuat dan melaksanakan program kerja yang akan dilaksanakan di desa yang sesuaikan dengan kondisisi desa serta kebutuhan masyarakat. Untuk itu perlu pengelolahan yang lebih jelas dan tersusun sehingga nilai dari program KKN yang dilaksanakan bukan hanya sekedar diadakan tetapi bagaimana memberikan suatu hal yang bermanfaat bagi masyarakat sehingga bisa menjadi manusia-manusia unggul, bermartabat dan memiliki kopetensi.

Bentuk dari pelaksanaan Kuliah Kerja Nyata (KKN) yaitu suatu kegiatan dari pengalaman ilmu pengetahuan dan wawasan yang didapatkan oleh mahasiswa selama perkuliahan yang mana ilmu tersebut akan diaplikasikan kepada masyarakat. Kuliah Kerja nyata ( $\mathrm{KKN}$ ) dilaksanakan secara melembaga dan terstruktur sebagai bagian pelaksanaan kurikulum pendidikan tinggi. Dalam artikel ini, kuliah kerja nyata (KKN) mahasiswa kelompok 157 Universitas Islam Negeri Sumatera Utara (UINSU) melakukan kegiatan sebuah acara "Seminar Literasi" di Perumahan Indah Permai, Desa petatal, Kabupaten Batu Bara, Provinsi Sumatera Utara.

Seperti yang kita ketahui, anak-anak usia dini literasinya begitu rendah, bahkan bukan anak-anak saja tetapi orang dewasa pun memiliki tingkat literasi yang rendah. Untuk membantu agar literasi pada anak meningkat maka perlunya pengembang literasi dasar pada diri anak tersebut. Literasi dasar adalah kemampuan dasar berliterasi yang harus dimiliki oleh anak sedari dini. Kemampuan literasi tersebut berupa membaca dan menulis. Kemampuan ini kelak akan menjadi bekal bagi anak dalam menghadapi perkembangan zaman. Namun rendahnya minat literasi masyarakat salah satu permasalahn yang sedang terjadi dalam dunia pendidikan indonesia sekarang ini. Penting bagi kita untuk menanamkan literasi kepada anak sejak dini. Dengan demikian, literasi dasar yang dapat kita kembangkan pada anak sedari dini yaitu membaca dan menulis. Seperti yang kita ketahui anak-anak usia dini sekarang lebih gemar bermain handphone dari pada membaca atau menulis buku. Hal tersebut yang menyebabkan minat literasi membaca dan menulis anak menurun. Dengan demikian pengembang literasi dasar dalam meningkatkan minat baca dan tulis pada anak bisa dilakukan dengan berbagai macam kegiatan, yaitu salah satu membacakan dongeng kepada anak, membuat waktu membaca dann menulis kepada anak, dan lain-lain.

\section{Metode}

Dalam melaksanakan kegiatan Kuliah Kerja Nyata (KKN) kelompok 157, metode yang digunakan yakni melalui penelitian lapangan. Penelitian tersebut termasuk ke dalam penelitian deskriptif kualitatif. Penelitian deskriptif kualitatif merupakan suatu metode atau cara penelitian dengan tujuan untuk menggambarkan kejadiankejadian yang ada serta menggambarkan suatu keadaan dan kondisi dengan ala kadarnya. Lokasi kegiatan acara Seminar Literasi KKN kelompok 157 yaitu di Perumahan Indah Permai Desa Petatal, Kecamatan Lima Puluh, Kabupaten Batu Bara. Acara seminar literasi ini dilaksanakan pada tanggal 19-Juli-2021. 
Subyek dalam penelitian ini adalah seluruh anggota KKN kelompok 157, pemateri, dan tamu undangan serta anakanak usia dini tingkat SD/TK. Sedangkan yang menjadi obyeknya adalah mengembangkan literasi dasar dalam meningkatkan minat membaca dan menulis pada anak usia dini melalui kegiatan acara Seminar Literasi yang diadakan oleh mahasiswa/i KKN kelompok 157 agar literasi dasar pada anak terus berkembang dan dapatmeningkatkan minat baca dan tulis pada anak sejak dini.

Penelitian ini menggunakan teknik pengumpulan data dengan cara observasi, wawancara dan dokumentasi. Penelitian ini menggunakan bentuk redukasi data, penyajian data, dan penarikan kesimpulan atau verifikasi.

\section{Hasil dan Pembahasan}

Pada saat anak masih di usia kanakkanak mereka lebih cenderung bermain dari pada belajar atau mengerjakan suatu kegiatan. Namun bukan berarti orang tua/wali terus membiarkan anak-anak menghabiskan waktunya untuk bermain saja. Bermain merupakan kegiatan yang digemari anak-anak, namun dalam kegiatan bermain, anak-anak juga harus diajarkan kegiatan pembelajaran literasi. Orang tua/wali harus berperan penting dalam mengajarkan dan mengembangkan literasi kepada anak. Terkait dengan hal tersebut, kegiatan literasi yang bisa diajarkan atau diterapkan kepada anak sejak dini yaitumembaca, dan menulis. Kegiatan membaca dan menulis tersebut merupakan literasi dasar. Literasi Dasar, merupakan kemampuan dan pemahaman seseorang dalam berbicara, membaca, menulis, menghitung dan mendengarkan yang berkaitan dengan kemampuan menganalisis informasi dalam pengambilan kesimpulan. Maka penting untuk mengajarkan dan mengembangkan kemampuan literasi membaca dan menulis pada anak sejak dini agar anak memiliki kemampuan literasi yang baik, kemampuan komunikasi yang baik, dan berpikir secara kritis serta kreatif.

Anak-anak usia dini tentunya belum paham mengenai apa itu literasi dan hal-hal lainnya yang terkait dengan literasi tersebut. Dengan demikian perlunya mengajarkan literasi dasar pada anak sejak dini. Maka dari itu, Mahasiswa/i Kuliah Kerja Nyata (KKN) kelompok 157 UINSU mengadakan kegiatan sebuah acara seminar Literasi di Desa Petatal, Kabupaten Batu Bara. Acara ini diadakan bertujuan untuk mengajarkan literasi sekaligus mengembangkan minat literasi membaca dan menulis pada diri anak sejak dini. Acara Seminar Taman Literasi ini dihadiri 20 anak-anak tingkat SD/TK, sekretaris Dinas Perpustakaan Batu Bara, Ikatan Generasi peduli (IGP), dan mahasiswa/i dari Universitas lain. Mahasiswa/i KKN kelompok 157 juga mengundang Bus Perpustakaan Batu Bara. Selama acara seminar tersebut berlangsung dipastikan setiap orang mematuhi protokol kesehatan dengan memakai masker, dan menyemprotkan handsanitizer pada tangan.

Dalam hasil wawancara dengan anakanak yang hadir diacara Seminar Literasi tersebut sebahagian dari mereka sudah memiliki kemampuan membaca dan menulis yang baik, namun ada beberapa anak yang kemampuan membaca dan menulisnya belum cukup baik. Anak-anak tersebut hanya membaca buku dan menulis saat belajar disekolah saja dan hanya sesekali membaca buku dan menulis saat berada dirumah. Mereka lebih sering bermain dari pada membaca dan menulis. Hal tersebut merupakan salah satu penyebab yang menjadikan minat literasi membaca dan menulis anak rendah. Untuk mengembangkan minat literasi membaca dan menulis pada anak-anak tersebut, acara seminar literasi yang dibuat oleh Mahasiwa/i KKN kelompok 157 dilakukan dengan upaya untuk mengembangkan literasi dasar dalam meningkatkan minat baca dan tulis anak-anak usia dini. Ada beberapa kegiatan-kegiatan yang diselenggarakan dalam acara seminar 
literasi ini yang bertujuan mengembangkan literasi dalam meningkat minat baca dan tulis pada anak usia dini, yaitu diantaranya:

\section{Kegiatan Penyampaian Materi Mengenai Literasi}

Kegiatan yang pertama dalam acara ini adalah penyampaian materi tentang literasi. Penyampaian materi ini ditujukan kepada anak-anak tingkat SD/TK yang hadir pada acara tersebut. Dalam penyampain materi dalam seminar ini ada 2 orang yang menjadi pemateri yang akan menyampaikan informasi mengenai apa itu literasi, manfaat dan tujuan, peran literasi dalam meningkatkan minat baca dan tulis. Pemateri yang pertama yaitu Bapak Sekretaris Dinas Perpustakaan Batu Bara dan pemateri yang kedua yaitu seorang Mahasiswa sekaligus relawan literasi. Dengan penyampaian materi tentang literasi dasar tersebut diharapkan agar anak-anak dapat mengerti serta tahu tentang literasi dan dapat menambah ilmu dan pengetahuan bagi mereka. Bukan hanya itu saja, dengan penyampain materi tersebut, anak-anak bisa memahami bahwa pentingnya literasi bagi diri sendiri sekaligus dapat mengembangkan potensi literasi dalam diri mereka yang dapat meningkatkan minat baca dan tulis pada diri mereka.

\section{Kegiatan Peminjaman Buku}

Peminjaman buku adalah kegiatan di mana anak-anak yang hadir dalam acara literasi tersebut melakukan peminjaman buku sesuai dengan keinginan dan kebutuhan mereka. Kegiatan meminjam buku ini dilakukan di Bus Perpustakaan Dinas Batu Bara yang telah diundang oleh Mahasiswa/i KKN kelompok 157. Setelah anak-anak mendapatkan buku yang mereka inginkan, kemudian anak-anak tersebut diarahkan untuk membaca buku yang mereka pinjam. Supaya anak-anak memahami isi buku yang dibacanya, maka anak-anak mendapatkan arahan atau tugas untuk menceritakan kembali kesimpulan yang didapat dari buku yang dibaca.

Panitia acara menunjuk satu anak untuk menceritakan kembali isi buku yang telah dibacanya. Kemudian, panitia memberi pertanyaan pengajaran apa yang bisa didapatkan dari isi buku tersebut. Melalui sesi tanya jawab ini, anak-anak didorong kemampuannya dalam memahami isi buku, ini bertujuan agar anak-anak mampu berpikir positif dan kritis. Dengan diadakan kegiatan peminjaman buku, perkembangan minat baca anak bisa dilihat dari beberapa aspek yaitu sebagai berikut:

a. Kesenangan anak dalam mencari dan mimilih buku bacaan. kegiatan peminjaman buku tersebut membuat anak menjadi aktif dan menumbuhkan kecintaannya terhadap buku bacaan. Hal tersebut bisa membantu mengembangkan literasi pada anak serta bisa meningkatkan minat baca dan tulis. Dengan begitu tumbuh kesadaran anakanak mengenai pentingnya membaca buku.

b. Rasa suka pada buku. Kegiatan acara seminar literasi melalui program peminjaman buku merupakan hal yang bisa membuat anak-anak suka dan senang terhadap buku bacaan. Dengan ini dapat membuat anak suka dan senang setelah sering meminjam buku baik di perpustakaan ataupun tempat baca lainnya. Hal ini dapat kita lihat dari antusiasnya anak-anak terhadap buku bacaan.

c. Ketertarikan pada buku. Kegiatan peminjaman buku bisa membuat anakanak tertarik terhadap buku semakin meningkat. Ketertarikan terhadap buku bacaan bisa membuat anak menjadi sering melakukan aktivitas membaca. Anak-anak begitu antusias ketika anakanak tersebut ditugaskan untuk berkunjung ke perpustakaan sekaligus meminjam buku untuk dibaca.

\section{Game Tebak Nama Hewan Dan Buah}

Tebak nama hewan dan buah dalam acara seminar literasi ini merupakan game edukasi yang dapat mengasah pikiran anakanak tersebut. Game ini bertujuan untuk mengasah pikiran anak-anak supaya anakanak tersebut dapat berfikir kritis dan positif. Dalam game tebak nama hewan dan 
buah ini, anak-anak diusahakan cepat dan tanggap dalam menjawab atau menyebutkan nama hewan atau buah dari petunjuk yang diberi oleh panitia acara.

Game edukasi tersebut dapat juga mengembangkan literasi baca dan tulis pada anak, jika seorang anak befikir kritis maka anak tersebut membiasakan mengasah pikirannya dengan hal yang positif salah satunya yaitu membaca buku dan menulis sebuah cerita atau karangan pendek. Dengan begitu literasi dalam diri anak bisa berkembangan lebih baik.

\section{Kegiatan Story Telling Untuk Anak- Anak}

Story telling merupakan cara meningkatkan kemampuan komunikasi dan bahasa pada anak, kemampuan mambaca serta dapat membuat anak senang dan cinta terhadap buku bacaan. Ketika melakukan story telling pada anak ini bertujuan membantu anak dalam keterampilan komunikasi, keterampilan membaca dan menulis, mendengarkan serta paham alur cerita.

Story telling merupakan suatu kegiatan penyampaian cerita kepada anakanak dari bahan bacaan. Kegiatan story telling bisa berupa mendongeng atau bercerita memerankan tokoh dari cerita tersebut untuk menarik perhatian anakanak. Ada beberapa manfaat story telling untuk anak yaitu sebagai berikut:

a. Kecerdasan emosional atau perasaan anak, ketika melakukan story telling untuk anak, perasaan atau emosional anak mulai bangkit, sehingga dapat memperkuat emosional dan perasaan pada anak. Pesan dan nilai pendidikan yang terkandung dalam cerita tersebut akan menumbuhkan rasa peduli anak. Dengan begitu anak dapat memahami emosi dan perasaan pada dirinya dan orang lain.

b. Kelancaran komunikasi dan bahasa anak, story telling merupakan cara yang efektif dalam meningkatkan kemampuan komunikasi dan bahasa anak. Melakukan story telling pada anak akan membantu cara berkomunikasi lebih baik dan menambahkan kosa kata anak.

c. Menumbuhkan kreativitas anak, kreativitas anak tumbuh dari pelajaran yang diberikan orang tua. Contohnya rajin bercerita kepada anak, dengan begitu ide-ide baru pada anak terus bertambah.

Kegiatan story telling di acara seminar literasi ini, buku yang dipinjam anak-anak di Bus Perpustakaan Dinas Batu Bara akan diceritakan kembali. Kegiatan tersebut begituefektif dalam menumbuhkan percaya diri bagi anak, mengembangkan pikiran kritis pada anak, serta meningkat minat baca yang tinggi bagi anak. Dalam kegiatan story telling tersebut, panitia acara akan menceritakan isi dari sebuah buku cerita lalu anak-anak diarahkan untuk mendengarkan. Setelah itu, diterjadi komunikasi antara panitia acara dengan anak-anak tersebut tentang isi buku cerita. Kemudian panitia acara mengajukan pertanyaan kepada anak-anak tentang kesimpulan isi buku tersebut. Panitia acara juga menjelaskan pelajaran moral apa yang bisa didapat dari buku yang dibaca.

\section{Kegiatan Lain yang Dapat Mengembangkan Literasi pada Anak Usia Dini}

Selain beberapa kegiatan pengembangan literasi dalam meningkat minat baca dan tulis pada anak yang diadakan oleh mahasiswa/i KKN kelompok 157 dalam acara seminar literasi tersebut, ada beberapa kegiatan lain yang bisa diterapkan atau diajarkan kepada anak usia dini untuk mengembangkan minat literasi membaca dan menulis di dalam dirinya antara lain sebagai berikut:

a. Membacakan buku cerita anak atau mendongeng pada anak

b. Mengajak anak ke toko buku

c. Membelikan atau menghadiahkan sebuah buku

d. Mengasah anak untuk menulis dengan memberikan tugas menulis karangan pendek tentang pengalaman yang paling bahagia bagi anak tersebut 
e. Memberikan pelatihan untuk menggambar dan mewarnai kepada anak

f. Melakukan kunjungan ke perpustakaan untuk membaca.

\section{Simpulan}

Pengembangan literasi yaitu suatu usaha yang dilakukan untuk mengembangkan kemampuan literasi seseorang dengan pelatihan, serta pendidikan. Pengembangan literasi tersebut bertujuan dalam mengembangkan kemampuan untuk memahami suatu bacaan dan mengolah kemampuan komunikasi secara kreatif dengan membaca. Mengembangkan literasi pada anak sejak dini sangat penting. Bermain suatu kegiatan yang digemari anak-anak, namun dalam kegiatan bermain, anak-anak harus diberikan kegiatan pembelajaran literasi. Dengan demikian, kegiatan literasi yang bisa diajarkan atau diterapkan kepada anak sejak dini yaitu kegiatan membaca, dan menulis. Membaca dan menulis termasuk salah satu jenis literasi dasar. Literasi Dasar, merupakan kemampuan dan pemahaman seseorang dalam berbicara, membaca, menulis, menghitung dan mendengarkan yang berkaitan dengan kemampuan menganalisis informasi dalam pengambilan kesimpulan. Maka penting untuk mengajarkan dan mengembangkan kemampuan literasi membaca dan menulis pada anak sejak dini gunanya agar anak memiliki kemampuan literasi yang baik, kemampuan komunikasi yang baik, dan berpikir secara kritis serta kreatif.

Untuk mengembangkan minat literasi membaca dan menulis pada anak-anak tersebut, acara seminar literasi yang dibuat oleh Mahasiwa/i KKN kelompok 157 dilakukan dalam upaya mengembangkan literasi dasar untuk meningkatkan minat baca dan tulis anak-anak usia dini. Ada beberapa kegiatan yang diselenggarakan dalam acara seminar literasi ini yang bertujuan dapat mengembakan literasi minat baca dan tulis pada anak usia dini, yaitu: a. Kegiatan penyampaian materi mengenai Literasi dan minat baca dan tulis

b. Kegiatan peminjaman buku di Bus Perpustakaan Dinas Batu Bara

c. Kegiatan atau game tebak nama hewan dan buah.

d. Kegiatan story telling

Ada beberapa kegiatan lain yang bisa diterapkan atau diajarkan kepada anak usia dini dalam mengembangkan minat literasi membaca dan menulis di dalam dirinya antara lain sebagai berikut:

a. Membacakan buku cerita anak atau mendongeng pada anak

b. Mengajak anak ke toko buku

c. Membelikan atau menghadiahkan sebuah buku

d. Mengasah anak untuk menulis dengan memberikan tugas menulis karangan pendek tentang pengalaman yang paling bahagia bagi anak tersebut

e. Memberikan pelatihan untuk menggambar dan mewarnai kepada anak

f. Melakukan kunjungan ke perpustakaan untuk membaca di sekolah.

\section{Daftar Pustaka}

[1] Dalman. (2013). Keterampilan Membaca. Jakarta: PT. Rajagrafindo Persada.

[2] Devianty, Rina. (2019). Manfaat Literasi untuk Meningkatkan Mutu Pendidikan. ljtimaiyah: Jurnal Ilmu Sosial dan Budaya, 3(1). http://jurnal.uinsu.ac.id/index.php/ijtim aiyah/article/view/7895.

[3] Kamah, I. (2002). Pedoman Pembinaan Minat Baca. Jakarta: Perpustakaan Nasional RI.

[4] Kharizmi, M. (2015). Kesulitan Siswa Sekolah Dasar dalam Meningkatkan Kemampuan Literasi. Jurnal Pendidikan Dasar (JUPENDAS), 2(2). http://jfkip.umuslim.ac.id/index.php/jup endas/article/view/233. 
[5] Prasetiyani. (2019). Mengembangkan Minat Baca Anak Usia Dini Melalui Kegiatan Literasi Perpustakaan di TK Masyitoh 25 Sokaraja. Skripsi. Purwokerto: IAIN Purwokerto. http://repository.iainpurwokerto.ac.id/5 230/.

[6] Lisnawati, I. \& Ertinawati, Y. (2019). Literat Melalui Presentasi. Metaedukasi: Jurnal Ilmiah Pendidikan, 1(1). http://jurnal.unsil.ac.id/index.php/meta edukasi/article/view/976.

[7] Rohmad, A. (2009). Kapita Selekta Pendidikan. Yogyakarta: Teras.

[8] Salahuddin, M. (1990). Pengantar Psikologi Pendidikan. Surabaya: Bina Ilmu.
[9] Shaleh, A. R. \& Wahab, M. A. (1976). Didaktik Pendidikan Agama. Jakarta: Bulan Bintang.

[10] Slameto. (2010). Belajar dan Faktorfaktor yang Mempengaruhinya. Jakarta: Rineka Cipta.

[11] Susanto, A. (2013). Teori Belajar dan Pembelajaran di Sekolah Dasar. Jakarta: Kencana.

[12] Syah, Muhibbin. (2006). Psikologi Belajar. Jakarta: PT. Rajagrafindo Persada.

[13] Syah, Muhibbin. (2015). Psikologi Belajar. Jakarta: PT. Rajagrafindo Persada. 